\title{
SOCIAL MEMORIES IN (POST)COLONIAL FRANCE: REMEMBERING THE FRANCO-ALGERIAN WAR
}

For the last thirty-five years or so, social memories have become more "problematic" - at least to manage - in France. French historian Jean-Pierre Rioux in his book La France perd la mémoire (France is Losing its Memory) situates this shift in the early 1970s and clearly laments challenges to traditional historiography or the Republican national "story." Pierre Nora too, editor of the multi-volume Realms of Memory which has become a key reference work in memory studies, sees the 1970s as inaugurating new relationships to the past in France-brought about by the death of President Charles de Gaulle, the social upheaval of May 1968, the end of grand narratives, the "acceleration of history," and economic stagnation. As Nora puts it, there are "sites or realms of memory" because there are no longer "real environments of memory." We should add that during the 1970s the questioning of the occlusions and comforting myths of the previous decades finally took place in the public sphere. ${ }^{2}$ Questioning the activities of the Vichy regime (1940-44) clearly dominated much memory work in France during the 1970s and 1980s, due to the profound legacy of the Holocaust in Europe and complex ethical and practical issues relating to French involvement in it.

More recently (essentially since the 1990s), a set of issues that can be grouped as (post)colonial have emerged more forcefully: for instance remembering, revisiting or re-evaluating the Franco-Algerian War (1954-62), the French Empire, slavery, or post-1945 immigration to France. ${ }^{3}$ Many of these historical debates, and especially the Algerian question-that take place in or through a variety of media such as films, novels, scholarship, commemorations, political declarations, activism, the media, and other channels or spheres-tend to be polemical as the periods considered are often still highly contested.

The renewed interest in historical memory is perhaps a particularly significant issue in France for several reasons. Firstly, the French nation has traditionally drawn heavily on historical references for its support. Such historical references helped to draw together what has always been an extremely divided and diverse nation. It was only in the relatively recent French Third Republic that the Republican system of government was finally adopted, and even then only after decades of political battle. The cost, however, was high, with, for example, regional identities suppressed. ${ }^{4}$ Twentieth Century history, after the "Sacred Union" of World War One ${ }^{5}$, has proven equally divisive and in a more open and modern society the traditional model has broken down. For Nora "In truth, the traditional model of commemoration has shattered". ${ }^{6}$ This model of commemoration has been destroyed and replaced by a more varied model that is "a splintered system, made 
up of disparate commemorative languages, that assumes a different relationship to the past, more elective than imperative, open, flexible, alive, and continually being reworked". ${ }^{7}$ French collective memory in general, therefore, appears to have become more fragmented, hence the use of the plural in the title of the third volume of Nora's collection: Les Lieux de mémoire: Les France.

While the traditional model of commemoration has broken down, the Republican paradigm is still quite resilient, albeit under pressure. This will be particularly relevant to my case study on (post)colonial memory, since one of the challenges to the Republican paradigm is precisely the (post)coloniality. As Alec Hargreaves points out, discussing ethnicity in the French Republic can be very difficult due to the focus on the individual citizen and general reticence to acknowledge intermediary groups between the State and the citizen. ${ }^{8}$ Similarly postcolonial theory has been slow to take hold in France ${ }^{9}$ and has only emerged in French in recent years. ${ }^{10}$ The old model is clearly under pressure. Its short term focus on forgetting and selective celebration of the Republic has proved inadequate over the last fifty years. This tradition of forgetting and repressionErnest Renan in his lecture "What is a Nation?" states that forgetting is necessary for a nation ${ }^{11}$ - has left many unresolved issues. The Algerian War was amongst other things a "latent civil war;" 12 it pitted French against French - for example, conscripts against putschists in 1961, or porteurs de valise ${ }^{13}$ against OAS - as well as Algerians against Algerians. Such divisive histories have long been repressed. The riots throughout many French cities in late 2005 showed the extent to which contemporary socio-economic exclusion actually functions along ethnic lines in France as well as the sheer scale of the problem. For several weeks pitched battles pitted young people living in the underprivileged outer suburbs (banlieues) of towns and cities against the police. Many of these young people are children or even now grand-children of migrants who came to France after World War Two from the then colonies of France such as Algeria. ${ }^{14}$ While such disturbances have been a regular occurrence since the early 1990s in a handful of particularly deprived suburbs such as Vénissieux on the outskirts of Lyon, 2005 was the first time riots of such severity, intensity and duration engulfed towns and cities throughout France. President Chirac may have campaigned in the 1995 Presidential campaign on a platform of combating the "social fracture," however over a decade later these issues have clearly been exacerbated rather than addressed. The trauma and bitterness of the colonial era and its bloody end, while appearing to belong to a far off period, are in reality unresolved as both Benjamin Stora and Kristin Ross have argued. ${ }^{15}$ Stora highlights the links between actors in the Algerian War and the French National Front extreme right political party. Ross identifies a powerful narrative or a discourse in France that has portrayed modernization and Empire separately and that makes the Empire appear as "ancient history" rather than as an event that did not end cleanly, and that impacted very directly and centrally on the lives of many people now alive in France. More and more of work in Francophone (post)colonial studies is highlighting the link between the colonial period and contemporary issues in France, notably around race. ${ }^{16}$ Here I want to add to this scholarship through a case study of one (post)colonial "memory battle" around the Algerian War (19541962). ${ }^{17}$ Through an analysis of various "vectors of memory" the paper argues that the recent upsurge in "memory work" in France is very much anchored in the present (post)colonial social context in France. That memory work is however 
largely symbolic and in some ways unsatisfactory. It shows that much of the recent work of memory has been only belatedly and partially undertaken by the State, with civil society in some ways yet to follow.

\section{Recent Work of Memory in France: the Franco-Algerian War}

Over forty-five years after the conflict ended, the Algerian War remains highly relevant to an understanding of contemporary French society due to its legacy, which has been difficult to work through and overcome. Yet its significance remains underestimated by many. Millions of people in today's France fought in or lived through the conflict. It lasted nearly eight years and was a fiercely fought campaign that caused huge division in French society. The war engendered the collapse of the Fourth Republic and caused immense rifts in France and Algeria as different communities emerged: such as professional soldiers, conscripts, OAS members (a far-right group of settlers and disgruntled army officers that sought by increasingly desperate, violent, and illegal means to keep Algeria French), ${ }^{18}$ gaullists, porteurs de valise (French who supported Algerian nationalists), harkis (Algerians who fought for the French army), and pieds-noirs (settlers). These groups are still very evident in French society today, often having formed associations and communities that tend to be hostile to one another. The conclusion of the war effectively heralded the end of over 130 years of French presence in Algeria and dealt the deathblow to the once mighty French Empire. Memories of the Algerian War now regularly (re)emerge directly in various polemical developments and debates in contemporary France. For example, the use of torture by the French army during the war was "discussed" in hundreds of articles during 2000-1 and later portrayed in Florent-Emilio Siri's 2008 film Ennemi Intime (Intimate Enemies).

The 1990s have witnessed an end to what Henry Rousso called the "obsession" with the Second World War, a shift that has occurred progressively over time due to a number of factors. A key turning point was undoubtedly the trial of Maurice Papon. In 1997 Frenchman Maurice Papon was finally tried in Bordeaux for his role as a civil servant during the Second World War. He was found guilty of crimes against humanity for his role in the deportation of Jews and served three years of a ten-year sentence in jail. In 2002 he was released early from jail on health reasons. He died five years later. Due to his age (he was eighty-seven years old when convicted), Papon's trial was the last "great memory trial" related to the Second World War to occur in France. During the war Papon had been the second top official in the Bordeaux region (Secretary General of the Prefecture of Gironde). After the Second World War he was a colonial administrator in Algeria, then Head of Police in Paris - at the time of the demonstration of 17 October 1961 when the French police killed dozens of Algerians in central Paris (an event whose painful legacy is examined in Michael Haneke's film Caché [Hidden]). During the Papon trial, the events of 17 October 1961 were discussed in court and received significant media coverage. The prosecution lawyers introduced this topic by calling writer Jean-Luc Einaudi to testify about what he knew about Papon's role on 17 October 1961. Einaudi, the author of La Bataille de Paris, became a pivotal witness in the trial. A journalist writing in the weekly magazine Le Point noted that the Algerian War was like Pandora's box: "Thirty years after the signing of the Evian peace agreement, the Algerian War emerged 
without warning in the witness stand during the Papon trial". ${ }^{19}$ Trials have not been a significant way in which memory work concerning the Algerian War has occurred because of a series of amnesties passed by the French government from the 1960s to the 1980s that have protected everyone from being prosecuted for activities during the war. ${ }^{20}$ Maurice Papon subsequently tried, unsuccessfully, to sue Einaudi. This episode led to further media coverage. During the trial a French judge, who is by definition a State representative, acknowledged for the first time that there was a "massacre" in Paris on 17 October 1961.

If as historian Robert Frank has argued, the Franco-Algerian War was not forgotten but rather occluded and repressed, then 1997 marks a key turning point for a certain official recognition of a state of "war" in Algeria between 1954 and 1962. For a very long time the Algerian War was referred to as "the war without a name". ${ }^{21}$ French authorities at the time depended on such descriptors as "pacification" or "peace-keeping" and this denial of what really happened in Algeria created an absence of language - one of Maurice Halbwachs' key social frames of memory - with which to speak of the events, thus hindering remembering. On 28 February 1999 a plaque was laid on the Arc de Triomphe that reads "To those who died for France during the Algerian War and the Conflicts in Tunisia and Morocco, 1952-62". Veterans in particular applauded this long overdue recognition of the reality of what they had lived through as young men that came about largely due to their campaigning.

This gradual shift in the public discourses around the conflict began in September 1997 when Jean-Pierre Masseret, Secretary of State for Veterans, first gave a speech in which he used the term "the Algerian War." ${ }^{22}$ The process was in a sense concluded on 10 June 1999, when the French Parliament passed a law making official the use of the term "Algerian War" in legal texts. JeanPierre Masseret personally played an essential role in this process and veterans' associations (through lobbying) were important in generating the necessary momentum. Masseret became a member of the Socialist-led government in 1997 which partly explains the timing of these moves but, it is important to note that from the late 1990s the veterans seemed to be wielding more and more influence demographically, socially, and politically. Perhaps this is due to the fact that many veterans were about to or were beginning to take retirement at this time, thus giving them more opportunity to invest time and energy in the activities of veterans' associations. Previous studies have also shown the way in which as people grow older they may want to come to terms with, and transmit, memories that they previously repressed..$^{23}$ Distance between the event being remembered and the present may also facilitate remembering.

Changes too have taken place at sites of memory. ${ }^{24}$ At the local level, thousands of "rues du 19 mars" (19 March Street) or steles have been created. A prominent veterans association, the FNACA, spearheaded this drive to memorialize using street names, by drawing on its strength, particularly at local level and in relation to local government. ${ }^{25}$ At the departmental level, almost every department now has its memorial. At the same time, a national memorial was created at Quai Bondy. It takes the form of three pillars, each with a list of names of victims that continually scrolls. There has also been greater recognition of the events of 17 October 1961, around sites of memory such as the plaque on the Saint Michel bridge in central Paris. Inaugurated by Bertrand Delanoë, Mayor of Paris, and member of the French Socialist Party, the plaque reads "In memory 
of the numerous Algerians killed during the bloody repression of the peaceful demonstration of 17 October 1961". The death of François Mitterrand in 1996, who had been Home Affairs Minister in the French government in 1954 at the beginning of the Algerian War, and the post-1997 return of the Left to power in the government led by Lionel Jospin undoubtedly helped advance discussions of the Algerian War during this period. Some aspects of the war, such as the events of 17 October 1961, resonate more fully with the Left. Political activism is definitely a key explanatory factor here. When Jim House and Neil MacMaster have come to analyse "how and why the memories of 17 October reinvested French society from the 1980s onwards, often as part of wider "memory battles" over the Algerian War', they have concluded that,

One key explanatory factor lies with the concerns of activists of Algerian origin, many of whose parents demonstrated on 17 October. These descendants of Algerians often came across 17 October via resilient counter-memories of French former anti-colonial activists rather than memory transmission within their own Algerian families. ${ }^{26}$

Harkis (Algerian soldiers who fought in the French army) have also received greater official recognition by the French State in the recent past. The history of the harkis was for many years regarded as one of the most occluded aspects of the Algerian War. ${ }^{27}$ They too now have received a site of memory, a plaque in the Invalides in Paris that reads: "The French Republic acknowledges its gratitude to the repatriated members of additional and assimilated forces or victims of captivity in Algeria for the sacrifices that they made". This memorial was inaugurated during the first National Day of Homage to the Harkis on 25 September 2001. Initially a one-off, this is now an annual commemoration. Here too activism has played a key role, as has a change in generation since it is the "sons and daughters of harkis" who have protested most actively. Sons have protested in regular demonstrations since $1974^{28}$ and daughters of harkis have recently used writing very effectively ${ }^{29}$. William Cohen believes political considerations are crucial to understanding this shift in memorialization: "The harkis, believed to be four hundred thousand strong in France, represented a significant electorate that needed wooing, so their cause was also being exploited by political rivals". ${ }^{30}$

The last ten years have undoubtedly witnessed a move by the French State and government to acknowledge the Algerian War far more than previously. Part of this shift can be explained by political considerations: the moderate right in particular has been keen to win over elements that might otherwise vote for the National Front. The National Front has traditionally drawn considerable support from former settlers, OAS members and harkis. ${ }^{31}$ Another explanation is more personal. Jacques Chirac (President of France, 1995-2007), for example, fought in Algeria. Chirac was twenty-three when he arrived in Algeria to lead thirty-two men between April 1956 and June 1957. He then returned to Algeria between July 1959 and March 1960 as a functionary. While Chirac was for some the "president of the duty of memory," President Nicolas Sarkozy seems intent on ending what he sees as the trend towards "repentance." Chirac personally played a leading role in much State level "work of memory, such as his 1995 recognition that France had committed "l'irréparable" (that which cannot be made up for) during the Vichy years. ${ }^{32}$ The Vichy period was very much the affair of the previous President of France, François Mitterrand. The "Algerian generation", 
on the other hand, was much more directly Jacques Chirac's generation, as it was a war in which he fought. Yet it is not at all clear that the generational change from Chirac to Sarkozy will facilitate French society's examination of its colonial past. It is also far from clear that the civil society has been particularly involved in these moves. My own work has shown the extent of lack of transmission of memories of the war in the three crucial vectors of the education system, the media, and the family. ${ }^{33}$

The Algerian War is little taught in schools. The wider subjects of Decolonization and the French Fourth/Fifth Republics are covered, but this leaves little room for the Algerian War itself. In other words, pupils may learn about Empires and their respective ends, but touch little on any specific account of French involvement in Algeria. There is virtually no time to invite veterans to class or to show films on the subject in an education system that is pedagogically very teacher centered. This treatment contrasts strongly with the teaching of the Second World War and the Vichy regime, which amounts to a quarter of the terminale (final year of high school) program. Unfortunately, the school system is unable to present much of the French historiography of the conflict produced since the early 1990s, and consequently the "memory battles" or "selective memories" that circulate in society cannot be engaged by historical knowledge. Few pages of textbooks are devoted to the war in Algeria, nor are many questions set on the topic at the baccalauréat (high school certificate) examination.

Similarly, it is rare for pupils to hear much about the Algerian War from their family. Veterans of the war in particular have been notoriously silent on the topic, for a variety of reasons, which include trauma, the sheer difficulty of confronting the experience and also a lack of interest from French society. All work in this area points to the silences and lack of dialogue in the millions of families affected by the war. ${ }^{34}$ This body of work examines a number of different groups that participated in various ways in the Franco-Algerian War-such as harkis, settlers, Algerian workers in France, or veterans. The common thread is a reluctance to talk about the war, particularly with family members.

One exception to this trend of the State-level domination of the re-working the Franco-Algerian War is "work of memory" in the media. This is another area that has proved very polemical. The media in recent years have been at the center of renewed examination of the Algerian War by French society. Throughout 2000 there was considerable media coverage in France on one of the most taboo aspects of the Algerian War: the French army's use of torture. ${ }^{35}$ Prior to this, the subject of torture was very rarely evoked and its discussion was limited to periodic eruptions occasioned by the publication in the early 1970s of General Massu's book La Vraie bataille d'Alger (The Real Battle of Algiers); or after the screening in France of Gillo Pontecorvo's film La Bataille d'Alger (The Battle of Algiers); or the discussion in the early 1980s of Jean-Marie Le Pen's activities in Algeria. ${ }^{36}$ This wave of media coverage lasted two years and has been described as a "very polemical and mediatized reactivation of the memory of the Algerian war" ${ }^{37}$ The coverage began in Le Monde when the paper first published the testimony of Louisette Ighilahriz. Ighilahriz described how she had been tortured by French forces and alleged that high ranking French army officers had been present, specifically Generals Jacques Massu and Marcel Bigeard — the former headed the Tenth Division of the French Paratroopers during the Battle of Algiers in 1957. In response to these allegations, Massu and Bigeard also published their own 
accounts in the paper, and over time other officers such as Generals Maurice Schmitt and Paul Aussaresses-the latter published the book Services Spéciaux: Algérie 1955-57 (Special Services: Algeria 1955-57) in 2001—were also accused of human rights violations. ${ }^{38}$ Judging by readers' letters, the coverage of the topic was polemical rather than reconciliatory.

Discussion of the Algerian War is still very difficult, particularly at a personal level. It is therefore to be expected that the State-level work of memory, first of all encouraged by the most active elements of civil society (early memory activists), and now followed by a broader section of civil society (film makers), will take time to impact on individuals and groups affected by the Algerian War.

\section{Conclusion}

Social memories of the Franco-Algerian War in France were for many years profoundly repressed and occluded, reflecting the immense trauma, shame and bitterness of a painful defeat. Individuals who participated in the Algerian War struggled to articulate what they had endured, people close to them often did not want to discuss those events, and the French government encouraged silence on the topic for the sake of national unity. However, over time, slowly but surely, such memories have evolved and emerged. What were once resolutely private memories have slowly entered the public sphere, often periodically around key commemorations (thirtieth and fortieth anniversaries of the end of the war in 1992 and 2002 respectively) and after a period of two or three decades as the participants have aged and retired and their children or grandchildren have grown up. The tireless work of "memory activists," from writers and scholars to political activists and filmmakers, has since the 1960s helped to shape a more clearly visible set of social memories. An acceleration in this process has occurred in France since the late 1990s, with a key shift in the stance of the French government and State, that had played such a key role previously in occluding memories of the war, and a number of explanations have been offered for these developments.

Given the variety of ways in which memories of Algeria have emerged, and the complex picture of repression and occlusion followed by progressive development of social memories, a number of theories of social memories need to be referred to in order to understand these patterns. These should reference the work of Maurice Halbwachs with his focus on the social frames of memory and the present social construction of memories. More psychological accounts of memory can shed light on the repression of memories. The passage of generations, both political (from Presidents Mitterrand to Chirac) and personal (from first generation migrants to their sons and daughters or grandchildren), helps explain how previously repressed events have slowly been uncovered. Lastly, the breadth of ways in which memories have been articulated in recent decades can be understood by reference to plural models of social memory that emphasize the role of individuals and groups in activating memories, such as that defended by Jay Winter and Emmanuel Sivan.

There has clearly been an important shift in social memories of the Algerian War in France over the last ten years. However, upon closer inspection, we can note that social memories of the Algerian War still clearly concern groups. In 1990 Jean-Pierre Rioux pointed to the lack of any national memory of the Algerian War, 
and highlighted the number of group memories that existed. Benjamin Stora too has identified what he calls "cloistered memories." Although the French State has acknowledged the plight of various groups in recent years, it has done so group by group. At present, the broader frames of memory that could move across groups, such as the education system, are not able to provide a forum for cross-group discussion. Although, as Stora has pointed out, "recognition" is a step forward from "knowledge" of what took place, ${ }^{39}$ we might also hope in coming years that discussion of France's role in Algeria is enlarged, more sustained and allows the various groups involved in the Algerian War to reconsider each other. There is a division between traditional Republican approaches to memory and more postcolonial challenges to this ${ }^{40}$, in so far as the traditional Republican model fears what Pierre Nora has termed a balkanization of memory and emphasizes the need for unity whereas memory activists like Yamina Benguigui, Mehdi Charef and Philippe Bernard believe that working through memories of the Algerian War is essential to the process of integration of ethnic minorities. The French State has now been able to integrate certain groups (such as soldiers and settlers) more centrally into the National narrative, and it remains to be seen if, to what extent, and how that inclusion will be extended to other groups and consolidated or developed in future years.

Faculty of Education and Society

St. Peter's Wayk, Sunderland

SR6 ODD

\section{ENDNOTES}

1. In French: "lieux de mémoire" and "milieux de mémoire." Translations from French into English are my own unless otherwise stated.

2. Henry Rousso's The Vichy Syndrome charts France's relationship to this past and identifies four periods. The period 1971-1974, in the wake of the events of May 1968 constitutes the "Broken Mirror" as the myths of the previous period are shattered-particularly in scholarship (notably from abroad, with American historian Robert Paxton's Vichy France: Old Guard, New Order showing the extent of French active collaboration with the Nazi occupier) and in film (with Marcel Ophül's The Sorrow and the Pity again challenging Gaullist myths of a united, large-scale French resistance whereby only "a handful of scoundrels" collaborate).

3. There has also been some "memory work" regarding the French war in Indo-China. See for example Cooper 2004. As Nikki Cooper argues, the conflict has little resonance in contemporary France. One explanation for this is that it was only professional soldiers who fought in Indo-China (whereas soldiers were drafted to Algeria) and another is the fact that Indo-China was not settled to anywhere the same degree as Algeria. See Dine 1994 for a full discussion of these points.

4. It is noteworthy that the outer regions of France, furthest from the Parisian centre, tend to have the strongest regional identities—and most active regionalist movements, such as in Brittany (North West) or Corsica (Mediterranean).

5. French history has usually been characterized by division, see Michel Winock's aptly entitled La Fièrre hexagonale (Hexagonal [French] Fever). This attention to discord can also be found in the concept of "guerres franco-françaises" (quasi civil wars) e.g. the Dreyfus Affair (1890s). However, World War One revealed a surprising consensus as previously belligerent parties (Left and Right, trade unions, religious groups, Republicans and monarchists) came together to defend the nation, hence the term "Sacred Union." 
6. "En vérité, le modèle traditionnel a éclaté."

7. Pierre Nora, ed., Les Lieux de mémoire. 3 vols (Paris, 1984-92), 983-985.

8. Alec G. Hargreaves, Immigration, "Race" and Ethnicity in Contemporary France (London and New York, 1995), 160-164; See also David Blatt, "Immigrant Politics in a Republican Nation," in Postcolonial Cultures in France, eds. Alec G. Hargreaves and Mark McKinney (London/New York, 1997), 160-164.

9. David Murphy, "De-centering French Studies: Towards a Postcolonial Theory of Francophone Cultures," French Cultural Studies 13 (2002): 165-185.

10. Pascal Blanchard, Nicolas Bancel and Sandrine Lemaire, La Fracture coloniale: la société française au prisme de l'héritage colonial (The Colonial Fracture: French Society in the Prism of its Colonial Heritage) (Paris, 2005).

11. For Renan two things constitute the spirit of a nation, and they are linked: "a rich legacy of memories" and "present-day consent, the desire to live together" (19).

12. Bernard Droz, "Le cas très singulier de la guerre d'Algérie" (The Unique Case of the Algerian War), Vingtième Siècle. Revue d'histoire 5 (January-March 1985): 81.

13. Porteurs de valise were French who helped the Algerian nationalists in their independence struggle, whereas OAS members belonged to the Organisation Armée Secrète (Secret Armed Organization) and violently opposed moves towards Algerian independence.

14. Between 1950 and 1974 the foreign population in France doubled. In 1946 Maghrebians (Moroccans, Algerians and Tunisians) constituted 3 percent of the foreign population, but by 1990 they represented 45 percent.

15. Benjamin Stora, Le Transfert d'une mémoire (The Transfer of a Memory) (Paris, 1999); Kristin Ross, Fast Cars, Clean Bodies: Decolonization and the Reordering of French Culture (Cambridge Massachusetts and London, 1995).

16. David Murphy, "De-centering French Studies; Sue Peabody and Tyler Stovall, The Color of Liberty: Histories of Race in France (Durham, 2003); Patricia M. E. Lorcin, Algeria and France, 18002000: Identity, Memory, Nostalgia (Syracuse, NY, 2006); Jo McCormack Collective Memory: France and the Algerian War (Lanham, MD, 2007).

17. By "memory battle" we mean a polemical dispute over different representations of the past. One example would be the battles over the date on which to commemorate the end of the Algerian War. On this particular question see Rouyard 1990. The official date of the beginning of the cease-fire (19 March 1962) is contested by many since thousands of pieds noirs and harkis were killed after this date, but it is defended as the logical date to commemorate the war by some veterans' associations.

18. OAS is an acronym for Organisation Armée Secrète, which translates into English as Armed Secret Organization.

19. François Dufay, "L'Octobre noir de Maurice Papon" (The Black October of Maurice Papon), Le Point 1311, 1 November 1997: 54.

20. Benjamin Stora, La Gangrène et l'oubli (The Gangrene and the Forgetting) (Paris, 1991).

21. John Talbott, The War Without a Name: France in Algeria, 1954-62 (London, 1981); Bertrand Tavernier and Patrick Rotman, La Guerre sans nom (The War Without a Name) (motion picture) France: Le Studio Canal + (1991).

22. "La guerre d'Algérie." He gave the speech in Pavie in the Gers département of France. 
23. Paul Thompson, The Voice of the Past: Oral History (Oxford, 1978).

24. For an excellent study of sites of memory related to the French Empire see Aldrich 2005.

25. Fédération Nationale des Anciens Combattants en Algérie, Maroc et Tunisie (National Federation of Veterans of Algeria, Morocco and Tunisia).

26. Jim House and Neil MacMaster, Paris 1961: Algerians, State Terror, and Memory (New York, 2006), 19.

27. Jean-Jacques Jordi and Mohand Hamoumou, Les harkis, une mémoire enfouie (Harkis, A Repressed Memory) (Paris, 1999).

28. William B. Cohen, "The Harkis. History and Memory," in Patricia M. E. Lorcin, ed., Algeria and France, 1800-2000: Identity, Memory, Nostalgia (Syracuse, NY, 2006), 164-180; Jean-Jacques Jordi and Mohand Hamoumou, Les harkis.

29. See Jo McCormack, Collective Memory

30. William B. Cohen, "The Harkis", 179.

31. See Benjamin Stora, Le Transfert d'une mémoire

32. "Commémorations, reconnaissance du rôle de l'Etat dans la déportation: Jacques Chirac a voulu regarder l'histoire en face. Mais reste sur un échec: les relations avec l'Algérie" (Commemorations, recognition of the French State's role in deportation: Jacques Chirac wanted to look squarely at the past. But there was one failed area: relations with Algeria). Gurrey 2007.

\section{See Jo McCormack, Collective Memory}

34. Yamina Benguigui, Mémoires d'immigrés, l'héritage maghrébin (Memories of Immigration: the Maghrebian Heritage) (Paris, 1997); Claire Mauss-Copeaux, Les Appelés en Algérie: la parole confisquée (Conscripts in Algeria: Confiscated Speech) (Paris, 1999); Laurent Muller, Le silence des harkis (The Silence of the Harkis) (Paris, 1999); Bertrand Tavernier and Patrick Rotman, La Guerre sans nom.

35. See Raphaëlle Branche, La Torture et l'armée pendant la guerre d'Algérie 1954-1962 (Torture and the Army during the Algerian War 1954-1962) (Paris, 2001).

36. Jean-Marie Le Pen is leader and founder of the National Front political party in France. The National Front has been a persistent presence since the early 1980s, although in the last election President Sarkozy did manage to weaken it by campaigning on themes that would appeal to its members. In 2002 Le Pen created a huge upset by beating the incumbent Prime Minister Lionel Jospin to the second round of the French Presidential election, where he faced Jacques Chirac. Le Pen was a paratrooper in Algeria. He has regularly been accused since the 1980s of torturing suspects during the Algerian War.

37. Jack Lang, speech given in August 2001, accessed at www.education.gouv.fr/discours/2001/ algeriejl.htm.

38. General Schmitt was the French Chief of Staff of the Army during the Gulf War under President François Mitterrand.

39. Benjamin Stora, Le Transfert d'une memoir, 240.

40. Richard L. Derderian, "Confronting the Past. The Memory Work of Second-Generation Algerians in France", in Patricia M.E. Lorcin, ed., Algeria and France, 247-256. 